\title{
Financial efficiency of rainwater utilization system in single-family house
}

\author{
Agnieszka Stec ${ }^{1, *}$ \\ ${ }^{1}$ Department of Infrastructure and Sustainable Development, Rzeszow University of Technology, \\ al. Powstańców Warszawy 6, 35-959 Rzeszów
}

\begin{abstract}
Designing of sustainable water systems should be aimed at reducing the consumption of tap water and the use of alternative water sources, such as rainwater and graywater. Therefore, the aim of the researches conducted was to determine the cost-effectiveness of the economic exploitation of rainwater utilization system in single-family house. As a tool for the analysis, the methodology Life Cycle Cost was used. It provides a comparison of different investment options and the opportunity to choose the one that is characterized by the lowest costs over the entire period of exploitation of the object. The research was conducted for four installation variants: the traditional solution and a solution in which rainwater was used for flushing toilets, washing and watering the garden. Variable parameters for calculations applied in the model were, among other things, different number of occupants and different length of exploitation of the installations. Additionally, the study included co-financing for the initial investment, which could be an incentive for residents to undertake this type of installation. The analysis conducted has shown that the systems with the use of rainwater enable significant reductions in the consumption of drinking water, while the variant with the traditional system was a most cost-effective solution only in few cases.
\end{abstract}

\section{Introduction}

A growth of the world's population, urbanization and climate changes, adversely affect water resources. According to numerous forecasts, the world's population will increase from the present level of 7.3 billion to 9.8 billion by 2050 [1] thus contributing to an increased global demand for water by 55\% [2]. Urban dwelling populations will, during the same period, also increase to about $66 \%$ [1]. These demographic changes and the resulting increase in consumption, combined with climate changes, will have adverse impacts on the functioning of municipal water and sewerage infrastructure and water resources management [3]. This creates the necessity to look for new technologies and alternative solutions that will result in total or partial withdrawal from the traditional, centralized water and wastewater management.

Climate changes observed in recent years also affect the amount and intensity of rainfall and they often cause the occurrence of floods and hydraulic overload of sewer systems [4]. To counteract these phenomena various devices and objects for retention and infiltration of

*Corresponding author: stec_aga@prz.edu.pl 
rainwater are used in catchments, as well as solutions which allow using rainwater installations in buildings $[5,6]$.

Designing of sustainable water systems should be aimed at reducing the consumption of tap water, among others, through the use of dredging batteries and devices to reduce the amount of water consumed, economic use of rainwater and recycling of gray water [7-9].

Economical use of rainwater can affect not only the protection of fresh water resources, but also reduce the financial outlays for the construction and maintenance of existing and new water supply networks $[10,11]$. Thanks to the fact that the collected rainwater from roofs of buildings has a low degree of contamination, it is most commonly used for purposes where quality of potable water is not required, and that its treatment will not require the use of sophisticated chemical and biological processes. Rainwater Harvesting Systems (RWHS) are primarily used for toilet flushing, watering green areas, washing, car washing and irrigation of farmland [12-15]. The applicability of RWHSs and water savings achieved depend on many factors which include: the amount of rainfall and the frequency of their occurrence and the demand for non-potable water. These parameters also affect the profitability of the financial implementation of these systems in buildings [16-18].

Taking this into consideration the aim of the research conducted was to determine the cost-effectiveness of the economical exploitation of rainwater utilization system in a singlefamily house located in Poland. As a tool for the analysis, the Life Cycle Cost methodology was used. It provides a comparison of different investment options and the opportunity to choose the one that is characterized by the lowest costs over the entire period of exploitation of the object. The research was conducted for four installation variants.

\section{Methodology}

In order to determine the cost-effectiveness of the application of the RWHS system and the possibility of saving potable water a financial analysis for four different variants of sanitary installations in the building was carried out:

- Variant 0 - traditional systems (Fig. 1),

- Variant 1 - installation with the use of rainwater for toilet flushing (Fig. 2),

- Variant 2 - Installation with the use of rainwater to toilet flushing and washing (Fig. 3),

- Variant 3 - Installation with the use of rainwater for toilet flushing, washing and watering the garden (Fig. 4).

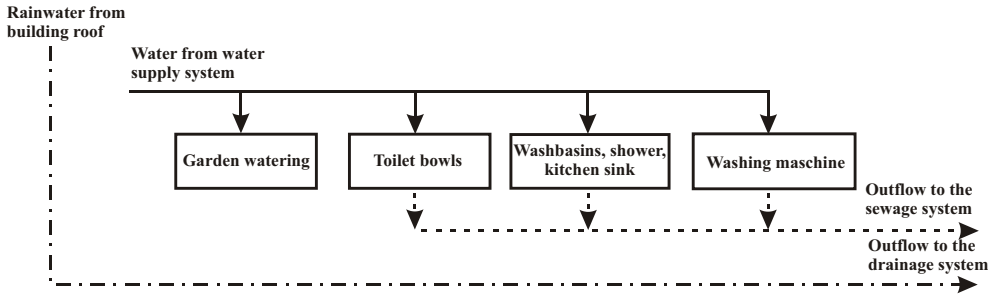

Fig. 1. The solution of installation in Variant 0.

In the study the Life Cycle Cost methodology was used which allowed to take into account all the costs connected with investment $(I N V)$ and use $(O C t)$ of a system and the residual value $(R V)$, which is the remaining value at the end of the study period [19]. $L C C$ costs for the variants of installation analyzed are based on the formula (1). However, according to the guidelines in the work [20] in justified cases when the life of the system exceeds the length of the period of analysis, the residual value can be omitted. Similar 
assumptions were made by other researchers who analyzed the financial efficiency of RWHSs [21]. Taking this into account and the assumed lengths of the $L C C$ analysis, the $R V$ value was not considered. It was also assumed that $\mathrm{T}$ parameter in the financial model was a variable parameter, thanks to which it was possible to determine the impact of the length of the analysis period on the profitability of the investment.

$$
L C C=I N V+\sum_{t=1}^{T}(1+r)^{-t} \cdot O C_{t}+R V
$$

where:

$I N V$ - investments, $€$;

$O C t$ - operating costs in the year $\mathrm{t}, €$;

$R V$ - residual value, $€$;

$T$ - duration of the $L C C$ analysis, years;

$r$ - constant discount rate;

$t$ - another year of the system use.

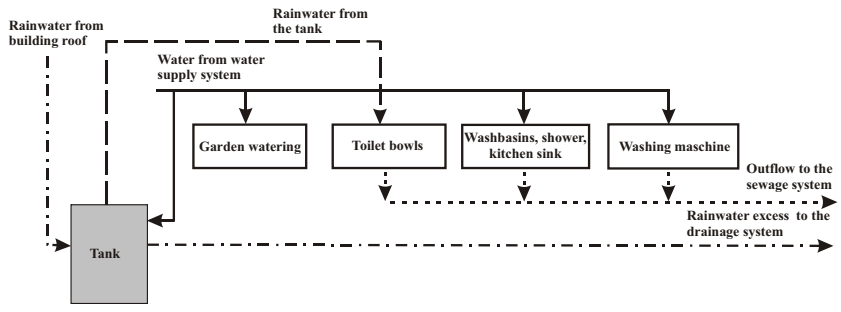

Fig. 2. The solution of installation in Variant 1.

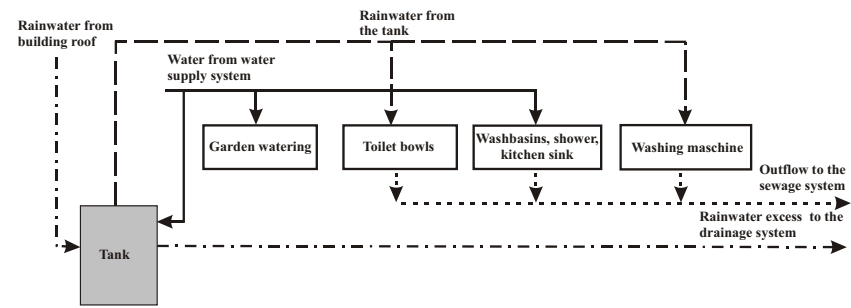

Fig. 3. The solution of installation in Variant 2.

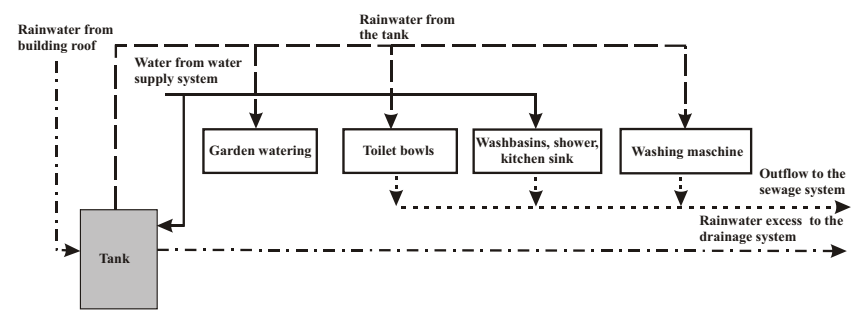

Fig. 4. The solution of installation in Variant 3.

The functioning of the system of rainwater harvesting was analyzed using a simulation model developed by Słyś [22]. This made it possible to determine the amount of rainwater that could be used or discharged into the sewerage system in each of the variants of the 
installation. Calculation algorithm of a simulation model applied was based on a daily water balance. A variable parameter of the simulation model was the number of users of the system (3, 4 and 5 people), which determined the size of the daily demand for water in the building, and this in turn affected the required capacity of the reservoir in the RWHS system.

\section{Case study}

Research to determine the financial efficiency of the use of RWHs was performed for a single-family building located in Rzeszów (the south-east part of Poland). A daily structure of water consumption in the building per capita is as follows: toilet flushing $-35 \mathrm{dm}^{3} / \mathrm{d}$, washing $-18 \mathrm{dm}^{3} / \mathrm{d}$, drinking and cooking $-4 \mathrm{dm}^{3} / \mathrm{d}$, washing up $-47 \mathrm{dm}^{3} / \mathrm{d}$, washing dishes $-12 \mathrm{dm}^{3} / \mathrm{d}$, cleaning and other needs $-8 \mathrm{dm}^{3} / \mathrm{d}$ [23]. It was also assumed that in the period from May to September, 3 times a week a backyard garden will be watered (area $500 \mathrm{~m}^{2}$ ), in the amount of $2,5 \mathrm{dm}^{3} / \mathrm{m}^{2}$ [24].

Rainwater from the roof of the building with an area of $150 \mathrm{~m}^{2}$ and a coefficient of runoff ratio of 0,9 will be discharged into an underground tank located near the building. In contrast, from the reservoir via the pump it will be transported to the inner system. On the basis of the demand for water for non-potable uses and guidelines for producers, rainwater tanks of $1,5 \mathrm{~m}^{3}$ for Variant 1 and of $2 \mathrm{~m}^{3}$ for Variants 2 and 3 were chosen. The exception for Variant 2 is the case when the system is used by 3 residents, where the volume of the reservoir is also $1,5 \mathrm{~m}^{3}$. In the calculations a 7-day period of storage of water in the tank is assumed. Because of the possibility of bacterial growth after this time the tank is emptied. In periods of shortage of rainwater the reservoir will be fed with water from the water supply network. However, during intense and prolonged rainfall an excess of water is drained from the tank to the sewage system.

In the simulation model actual rainfall data for Rzeszów from a 10-year period (2003-2012) was recorded. The average annual precipitation $H$ in the analyzed period amounted to $695 \mathrm{~mm}$.

\section{Input data of the financial model}

The data characterizing the building considered, and the inputs of the financial model are summarized in Table 1. Investments and unit costs resulting from the operation of the system were established on the basis of producer prices and the applicable tariffs for water supply and sewage disposal.

In each of the investment variants, in the $L C C$ analysis the initial investments $I N V_{0}$ arising from the implementation of internal plumbing and sewage were considered. In addition, in variants 1, 2 and 3 capital expenditure associated with the use of rainwater harvesting system were also considered. These costs for the installation of the tank with a capacity of $1,5 \mathrm{~m}^{3}$ amounted to 1448 euro while for the tank of $2 \mathrm{~m}^{3}$ the cost was 1728 euro. In view of the fact that the rainwater will be used for washing, the RWHS system in Variants 2 and 3 is additionally equipped with a filter-pipe.

In turn, the operating costs of each variant include the costs of purchasing water from the water supply and sanitary sewage to the sewage network and fees for draining rainwater to the sewage system (the whole water for Variant 0 , excess of water for Variant 1, 2 and 3 ). In Variant 1, 2 and 3 energy costs resulting from the transport of pumping water from the tank into the building and the cost of replacing a pump every 10 years of operation in the RWHS system were also taken into account. 
Table 1. Data used in the calculation of LCC costs.

\begin{tabular}{|c|c|}
\hline Parameter & Parameter value \\
\hline Analysis period $T$ & $15,20,25$ years \\
\hline $\begin{array}{c}\text { The annual increase in electricity prices } \\
\text { pipe network }\end{array}$ & $4 \%$ \\
\hline $\begin{array}{c}\text { The annual increase in the prices of purchase of water from the water- } \\
\text { The annual increase in the prices of rainwater discharge } \\
\text { to the sewage network }\end{array}$ & $6 \%$ \\
\hline $\begin{array}{c}\text { The annual cost of filter cartridges } \\
\text { to the sewage system }\end{array}$ & $6 \%$ \\
\hline The annual increase singe discharge & $€ 10$ \\
\hline The cost of purchasing electricity in the year 0 & $0.139 € / \mathrm{kWh}$ \\
\hline The cost of purchasing water from the water-pipe network in the year 0 & $0.880 € / \mathrm{m}^{3}$ \\
\hline The cost of sanitary sewage discharge to sewage network in the year 0 & $0.894 € / \mathrm{m}^{3}$ \\
\hline The cost of discharge of rainwater to the sewage network in the year 0 & $0.719 € / \mathrm{m}^{3}$ \\
\hline The cost of purchasing and installing the RWHS - tank $1,5 \mathrm{~m}^{3} I N V_{R W H S} 1,5$ & $€ 1448$ \\
\hline The cost of purchasing and installing the RWHS - tank $2 \mathrm{~m}^{3} I N V_{R W H S 2}$ & $€ 1728$ \\
\hline The cost of purchasing and installing the additionally filter $I N V_{F}$ & $€ 72$ \\
\hline The cost of purchasing and installing the sanitary systems $I N V_{0}$ & $€ 1920$ \\
\hline The discount rate $r$ & $5 \%$ \\
\hline
\end{tabular}

Increased initial investments resulting from the use of rainwater harvesting system can be a barrier for potential investors, for whom the financial criterion is the decisive one. In this connection, the studies were also conducted which included some subsidies to make variants of installation of the system of economic use of rainwater. The subsidies amounted to 15,30 and $45 \%$. Such aid for initial investment could come from the state budget or nongovernmental organizations, as in case of many countries around the world.

\section{Result and discussion}

The studies conducted on a simulation model of rainwater harvesting system functioning in the analyzed building showed that rainwater was not able to completely replace tap water required to meet the demand for water for non-potable uses. Depending on the installation variant and number of residents an decrease in total tap water per year ranged from $14,6 \%$ to $30,3 \%$. The high proportion of water from the sewage system in the water demand for non-potable uses is due to insufficient irregularity of the surface of the roof and the occurrence of precipitation during the year.

The results of simulation tests allowed to assess the effectiveness of financial investment on the utilization of rainwater in the building. The financial analysis showed that the use of Life Cycle Cost methodology in the evaluation of the profitability of the investment was the right choice, because the decision only on the basis of the initial investment might lead to the selection of a solution that in the long term might make very high operating costs. Based on the results obtained, which are listed in Table 2, it was found that only in 4 calculation cases the variant with conventional installations (Variant 0 ) was a solution with the lowest ratio of $L C C$. This was mainly in shorter periods of analysis when $T$ was 15 years. At the same time it should be noted that for these cases the differences in the values of this index between Variant 0 and Variant 3 were insignificant. It also turned out that during the longest period $T$ of 25 years, irrespective of the number of installation users, the best solution financially was always Variant 3, in which the rainwater was used for toilet flushing, washing and watering the garden. A similar situation with one exception was observed for the 20 -year analysis period. The exception is the case when the installation is utilized by 3 people. This is caused by less need for rainwater and, 
consequently, lower savings which result from water purchase from the network for 20 years. The least cost-effective option was the concept of the system where rainwater was used only for toilet flushing (Variant 1). Regardless of the number of inhabitants and the length of operation of the installation the highest values of $L C C$ were obtained.

Table 2. Summary of the results of Life Cycle Cost analysis for different investment variants.

\begin{tabular}{|c|c|c|c|c|c|c|c|c|c|}
\hline & \multicolumn{9}{|c|}{ The number of occupants } \\
\cline { 2 - 10 } Variant & \multicolumn{3}{|c|}{ 3 persons } & \multicolumn{3}{|c|}{ 4 persons } & \multicolumn{3}{c|}{$\mathbf{5}$ persons } \\
\cline { 2 - 10 } & $\begin{array}{c}T=15 \\
\text { years }\end{array}$ & $\begin{array}{c}T=20 \\
\text { years }\end{array}$ & $\begin{array}{c}T=25 \\
\text { years }\end{array}$ & $\begin{array}{c}T=15 \\
\text { years }\end{array}$ & $\begin{array}{c}T=20 \\
\text { years }\end{array}$ & $\begin{array}{c}T=25 \\
\text { years }\end{array}$ & $\begin{array}{c}T=15 \\
\text { years }\end{array}$ & $\begin{array}{c}T=20 \\
\text { years }\end{array}$ & $\begin{array}{c}T=25 \\
\text { years }\end{array}$ \\
\hline Variant 0 & 7426 & 9384 & 11410 & 8694 & 11115 & 13628 & 9961 & 12847 & 15846 \\
\hline Variant 1 & 8977 & 10339 & 12218 & 10138 & 11811 & 14105 & 11335 & 13360 & 16090 \\
\hline Variant 2 & 8850 & 9978 & 11741 & 10100 & 11447 & 13573 & 11286 & 12973 & 15530 \\
\hline Variant 3 & 8670 & 9393 & 10949 & 9879 & 10969 & 12968 & 11120 & 12613 & 15074 \\
\hline
\end{tabular}

Tests results presented in Table 2 show that the differences between the values of the $L C C$ for all analyzed variants and calculation cases are not great. This is an influence of additional investment costs in alternative installations supplied with rainwater, which are not fully compensated by lower operating costs obtained through the use of rainwater for non-potable uses. In addition the lower profitability of variants of RWHS is affected by the operating costs associated with the replacement of the pump every 10 years and the annual cost of replacement filter cartridges. In this regard the research was also carried out and it aimed at determining the effect of financing to make rainwater harvesting system in the single-family building. It was assumed that funding for the initial investment will amount to $15 \%, 30 \%$ or $45 \%$. The results of these tests are summarized in Tables 3,4 and 5 .

Based on the results obtained one can notice that a subsidy of up to $45 \%$ will not change the cost-effectiveness of the use of Variant 0 for the analysis period $T$ of 15 years. That means that in a shorter analysis period the reduction of the amount of potable water consumption, and the resulting from it cost savings due to RWHS application, does not fully compensate for the increased initial investment and the cost of replacing parts of the system. This will only reduce the differences in values of $L C C$ ratio between Variant 0 and other variants of investment. On the other hand, when the installation is utilized by 3 residents and $T=20$ years, the subsidy for initial investments in the amount of already $15 \%$ will change the most beneficial variant so far (Variant 0 ) in favor of Variant 3.

Table 3. Results of the $L C C$ analysis for different installation variants in the building, taking into account $15 \%$ of the funding for capital expenditure.

\begin{tabular}{|c|c|c|c|c|c|c|c|c|c|}
\hline & \multicolumn{9}{|c|}{ The number of occupants } \\
\cline { 2 - 11 } Variant & \multicolumn{3}{|c|}{ 3 persons } & \multicolumn{3}{|c|}{ 4 persons } & \multicolumn{3}{c|}{ 5 persons } \\
\cline { 2 - 11 } & $\begin{array}{c}T=15 \\
\text { years }\end{array}$ & $\begin{array}{c}T=20 \\
\text { years }\end{array}$ & $\begin{array}{c}T=25 \\
\text { years }\end{array}$ & $\begin{array}{c}T=15 \\
\text { years }\end{array}$ & $\begin{array}{c}T=20 \\
\text { years }\end{array}$ & $\begin{array}{c}T=25 \\
\text { years }\end{array}$ & $\begin{array}{c}T=15 \\
\text { years }\end{array}$ & $\begin{array}{c}T=20 \\
\text { years }\end{array}$ & $\begin{array}{c}T=25 \\
\text { years }\end{array}$ \\
\hline Variant 0 & 7426 & 9384 & 11410 & 8694 & 11115 & 13628 & 9961 & 12847 & 15846 \\
\hline Variant 1 & 8744 & 10105 & 11984 & 9904 & 11577 & 13871 & 11101 & 13126 & 15856 \\
\hline Variant 2 & 8605 & 9734 & 11497 & 9830 & 11177 & 13303 & 11016 & 12704 & 15260 \\
\hline Variant 3 & 8400 & 9123 & 10679 & 9609 & 10699 & 12698 & 10850 & 12343 & 14804 \\
\hline
\end{tabular}

Table 4. Results of the $L C C$ analysis for different installation variants in the building, taking into account $30 \%$ of the funding for capital expenditure.

\begin{tabular}{|c|c|c|c|c|c|c|c|c|c|}
\hline \multirow{3}{*}{ Variant } & \multicolumn{9}{|c|}{ The number of occupants } \\
\cline { 2 - 11 } & \multicolumn{3}{|c|}{ 3 persons } & \multicolumn{3}{c|}{ 4 persons } & \multicolumn{3}{c|}{ 5 persons } \\
\cline { 2 - 11 } & $\begin{array}{c}T=15 \\
\text { years }\end{array}$ & $\begin{array}{c}T=20 \\
\text { years }\end{array}$ & $\begin{array}{c}T=25 \\
\text { years }\end{array}$ & $\begin{array}{c}T=15 \\
\text { years }\end{array}$ & $\begin{array}{c}T=20 \\
\text { years }\end{array}$ & $\begin{array}{c}T=25 \\
\text { years }\end{array}$ & $\begin{array}{c}T=15 \\
\text { years }\end{array}$ & $\begin{array}{c}T=20 \\
\text { years }\end{array}$ & $\begin{array}{c}T=25 \\
\text { years }\end{array}$ \\
\hline Variant 0 & 7426 & 9384 & 11410 & 8694 & 11115 & 13628 & 9961 & 12847 & 15846 \\
\hline Variant 1 & 8510 & 9871 & 11750 & 9671 & 11343 & 13637 & 10867 & 12892 & 15622 \\
\hline Variant 2 & 8361 & 9489 & 11252 & 9560 & 10907 & 13034 & 10746 & 12434 & 14990 \\
\hline Variant 3 & 8131 & 8853 & 10410 & 9339 & 10429 & 12429 & 10580 & 12074 & 14534 \\
\hline
\end{tabular}


Table 5. Results of the $L C C$ analysis for different installation variants in the building, taking into account $45 \%$ of the funding for capital expenditure.

\begin{tabular}{|c|c|c|c|c|c|c|c|c|c|}
\hline & \multicolumn{9}{|c|}{ The number of occupants } \\
\cline { 2 - 10 } Variant & \multicolumn{3}{|c|}{$\mathbf{3}$ persons } & \multicolumn{3}{|c|}{ persons } & \multicolumn{3}{c|}{$\mathbf{5}$ persons } \\
\cline { 2 - 10 } & $\begin{array}{c}T=15 \\
\text { years }\end{array}$ & $\begin{array}{c}T=20 \\
\text { years }\end{array}$ & $\begin{array}{c}T=25 \\
\text { years }\end{array}$ & $\begin{array}{c}T=15 \\
\text { years }\end{array}$ & $\begin{array}{c}T=20 \\
\text { years }\end{array}$ & $\begin{array}{c}T=25 \\
\text { years }\end{array}$ & $\begin{array}{c}T=15 \\
\text { years }\end{array}$ & $\begin{array}{c}T=20 \\
\text { years }\end{array}$ & $\begin{array}{c}T=25 \\
\text { years }\end{array}$ \\
\hline Variant 0 & 7426 & 9384 & 11410 & 8694 & 11115 & 13628 & 9961 & 12847 & 15846 \\
\hline Variant 1 & 8276 & 9638 & 11516 & 9437 & 11109 & 13403 & 10634 & 12658 & 15388 \\
\hline Variant 2 & 8116 & 9244 & 11008 & 9290 & 10637 & 12764 & 10476 & 12164 & 14720 \\
\hline Variant 3 & 7861 & 8584 & 10140 & 9070 & 10159 & 12159 & 10310 & 11804 & 14264 \\
\hline
\end{tabular}

\section{Conclusions}

Economical use of rainwater for indoor and outdoor non-potable purposes makes it possible to reduce the consumption of tap water, and thus protect fresh water resources. It also reduces the amount of rainwater discharged into the sewerage system so improves their functioning. The search for alternative water sources is becoming increasingly important, since a climate change and the growing world population favor the occurrence of water deficits. In addition, fees associated with the operation of water supply and sewage systems in residential buildings represent a significant part of costs paid during the year for the use of the entire facility. Taking these problems into account, the analysis of Life Cycle Cost of the use of rainwater harvesting system in a residential building located in Poland was conducted.

The studies showed that rainwater can be a valuable source of water in the residential building. The use of rainwater for toilet flushing, washing and watering the garden can reduce the consumption of water from the water supply, depending on the variant of the installation, from almost $15 \%$ to over $30 \%$. The lowest investment costs are in Variant 0 , but after taking into account the operating costs, it turned out that only at the shortest period of analysis of 15 years, and low demand for rainwater, this option was still the most cost-effective. In all other cases, the lowest LCC value obtained for the variant where the rainwater was used to flush toilets, wash and water the garden (Variant 3). The use of rainwater harvesting system for toilet flushing only (Variant 1), or toilet flushing and washing (Variant 2) has a higher index values of $L C C$, but still for longer periods of analysis these options are more cost effective than the traditional solution for the installation.

The results of the financial analysis have a practical aspect and can be a valuable source of information for potential investors to use rainwater harvesting systems already at the stage of investment planning and decision-making. In addition, as confirmed also in studies, funding for initial investment will increase financial efficiency of the use of rainwater harvesting systems. This may be especially important in the case of single-family houses, for which, due to low demand for water resulting from the small number of residents, an implementation of rainwater harvesting system incurs very high investment.

\section{References}

1. The United Nations World Water Development Report 2015 Water For a Sustainable World. https://www.unesco-ihe.org/sites/default/files/wwdr_2015.pdf. Accessed 30 December 2016

2. OECD Environmental Outlook to 2050: The Consequences of Inaction, OECD Publishing, Paris. DOI: http://dx.doi.org/10.1787/9789264122246-en

3. A.S. Silva, E. Ghisi. Journal of Environmental Management 180, 82-93 (2016) 
4. B. Kaźmierczak, A. Kotowski. Theor. Appl. Climatol. 118, 285-296 (2014)

5. K. Pochwat, D. Słyś. Journal of Civil Engineering, Environment and Architecture 63, 359-369 (2016)

6. D. Słyś, A. Stec. Ecol. Chem. Eng. S 21, 623-635 (2014)

7. J.Y. Cheng Leong, K.S. Oh, P.E. Poh, M.N. Chong. J. Clean. Prod. 142, 3014-3027 (2017)

8. S. Kordana, D. Słyś, J. Dziopak. J. Clean. Prod. 82, 58-69 (2014)

9. A. Stec, S. Kordana. Resour. Conserv. Recy. 105, 84-94 (2015)

10. T.R. Gurung, A. Sharma. J. Clean. Prod. 67, 26-36 (2014)

11. C.M. Silva, V. Sousa, N.V. Carvalho. Resour. Conserv. Recycl. 94, 21-34 (2015)

12. E. Ghisi, P.N. Schondermark. Water Resour. Manag. 27, 2555-2576 (2013)

13. C. Matos, C. Santos, I. Bentes, M.A. Imteaz, S. Pereira. Water Resour. Manag. http://dx.doi.org/10.1007/s11269-015-1040-9.

14. R. Karima, M. Bashara, M.A. Imteaz. Resour. Conserv. Recy. 104, 61-67 (2015)

15. G. Markovič, D. Káposztásová, Z. Vranayová. Transactions on Environment and Development 10, 242-249 (2014)

16. S.R. Ghimire, J.M. Johnston, W.W. Ingwersen, T.R. Hawkins. Environ. Sci. Technol . 48, 4069-4077 (2014)

17. X. Liang, M.P. Van Dijk. Resour. Conserv. Recy. 55,1100-1108 (2011)

18. T. Morales-Pinzón, R. Lurueña, J. Rieradevall, C.M. Gasol, X. Gabarrell. Resour. Conserv. Recy. 69, 130-140 (2012)

19. S. Fuller, S. Petersen. Life Cycle Costing Manual for the Federal Energy Management Program/National Institute of Standards and Technology. NIST Handbook 135, the U.S. Department of Energy. Available: www.fire.nist.gov/bfrlpubs/build96/PDF/b96121.pdf (accessed November 2016)

20. Life Cycle Cost Handbook. Guidance for Life Cycle Cost Estimation and Analysis. Office of Acquisition and Project Management, U.S. Department of Energy, Washington. Available: www.energy.gov/sites/prod/files/2014/10/f18/LCC\%20Handbook\%20Final\%20Versio n\%209-30-14.pdf (accessed November 2016)

21. A. Rahman, J. Keane, A.M. Imteaz. Resour. Conserv. Recy. 61, 16-21 (2012)

22. D. Słyś. Water Environ. J. 23, 318-325 (2009)

23. J. Chudzicki, S. Sosnowski. Instalacje wodociągowe: projektowanie, wykonanie, eksploatacja, Wydawnictwo „Seidel-Przywecki” Sp. z o.o., Warszawa 2009.

24. Rozporządzenie Ministra Infrastruktury z dnia 14 stycznia 2002 r. w sprawie przeciętnych norm zużycia wody (Dz. U. $2002 \mathrm{Nr}$ 8, poz. 70) 